\title{
UPAYA PENINGKATAN MUTU PRODUK RUJAK BUAH (LOTIS) PEDAGANG KAKI LIMA DI PABELAN KARTASURA
}

\author{
1) Aan Sofyan, 2) Markhamah, 3) Andre Yusuf Tisna Putra, ${ }^{4)}$ Ulfah Rosyidah, ${ }^{5)}$ Iga Syafa 'atin, \\ ${ }^{6}$ Maulina Nur Puspitasari, ${ }^{7)}$ David Eka Pradinata, ${ }^{8}$ Irfan Ali \\ 1), 3), 4), 5), 6)Fakultas Ilmu Kesehatan, Universitas Muhammadiyah Surakarta \\ 1) email: aan.sofyan@ums.ac.id \\ ${ }^{2)}$ Fakultas Keguruan dan Ilmu Pendidikan, Universitas Muhammadiyah Surakarta \\ 2)email:markhamah@ums.ac.id \\ ${ }^{7), 8)}$ Fakultas Teknik, Universitas Muhammadiyah Surakarta
}

\begin{abstract}
This dedication program is an effort to solve partner problems. Partners coupled in this devotion program is a fruit salad or lotis merchant. The problems faced by partners are lack of knowledge about hygiene and sanitation in food processing (fruit salad/lotis). This condition is seen among others from carts used every day to sell salad/lotis salad. Wooden wagon material with coated paint is a hazardous material for use in food processing. Coat that is used to coat wood is a non-food grade material that can be included in the food sold. The purpose of this IbM program is to help partners improve wagon conditions by designing carts with safer materials by the principle of sanitation and food safety in food processing. Also, the purpose of this program is to increase knowledge about hygiene and sanitation for partners; this is done by providing reading media in the form of booklets that contain guidelines on the application of the principles of hygiene, sanitation and good food security in food processing. The next goal is to raise awareness of the partners always to maintain personal hygiene so that the opportunities of contamination from humans to food can be reduced or eliminated.
\end{abstract}

Keywords: rujak; buah; kakilima; sanitasi; higiene

\section{PENDAHULUAN}

\section{Analisis Situasi}

Pedagang kaki lima merupakan salah satu jenis kegiatan perekonomian masyarakat yang banyak diminati dalam upaya mencari penghasilan. Salah satu jenis usaha kaki lima yang mudah dijumpai di pinggiran jalan pada pusat keramaian yaitu pedagang rujak buah atau ada yang menyebutnya pedagang lotis. Para pedagang ini menjajakan barang dagangan berupa irisan berbagai macam buah yang dihidangkan lengkap dengan sambal. Para pedagang tersebut menggunakan gerobak sebagai etalase atau tempat untuk "memamerkan" barang dagangan mereka.

Kualitas produk merupakan pertimbangan utama seorang konsumen dalam memilih barang yang akan dibeli. Menurut Maria dan Anshori (2013) kualitas produk berpengaruh positif terhadap kepuasan konsumen. Hal itu pun berlaku pada komoditi atau jenis produk makanan (Maria dan Anshori, 2013). Makanan yang dikonsumsi bukan hanya untuk menghilangkan rasa lapar tetapi juga dari aspek kesehatan makanan merupakan salah satu cara dalam pemenuhan kebutuhan gizi tubuh. Buah merupakan salah satu alternatif makanan yang dapat memenuhi kebutuhan gizi terutama kandungan vitamin yang diperlukan oleh tubuh.

Buah merupakan salah satu bahan pangan yang mudah sekali mengalami kerusakan karena mengandung hampir 100\% 
air. Hal ini menyebabkan buah mudah sekali mengalami pembusukan akibat pengaruh aktifitas mikrobia, terlebih ketika buahbuahan tersebut sudah dikupas. Menurut Rickman (2007) buah dan sayuran biasanya memiliki lebih dari $90 \%$ air dan, setelah dipanen, mulai mengalami pengingkatan respirasi yang lebih tinggi, sehingga mengakibatkan hilangnya kelembaban, kerusakan kualitas dan potensi pembusukan mikroba. Buah yang sudah dalam keadaan terkupas sangat rentan terhadap kontaminasi mikrobia.

Hasil observasi di lapangan menunjukkan kondisi para mitra baik mitra Bapak Sihman maupun mitra Bapak Uyan yaitu sama-sama menggunakan gerobak dari kayu. Dari segi aspek sanitasi dan hygiene makanan gerobak yang digunakan belum memenuhi persyaratan kebersihan. Gerobak yang digunakan berbahan dasar dari kayu yang dilapisi oleh cat. Hal ini tentunya tidak dianjurkan karena kondisi peralatan atau tempat yang kontak dengan makanan langsung harus benar-benar bersih dan juga aman. Permukaan kayu yang dilapisi cat ketika kontak atau bersentuhan langsung dengan makanan atau buah-buahan yang sudah terkupas dapat berpeluang terjadinya bahaya kimia.

Kebersihan diri para mitra penjual rujak buah baik Bapak Sihman maupun Bapak Uyan belum sesuai dengan penerapan prinsip hygiene personal yang benar. Para mitra penjual rujak buah tidak menggunakan peralatan pelindung diri yang dapat mengurangi kontaminasi dari tubuh ke produk makanan. Kedua mitra tidak menggunakan apron yaitu standard perlengkapan yang wajib digunakan untuk pengolah makanan (food handler). Selain itu kebersihan tangan para pedagang buah tersebut belum begitu diperhatikan. Idealnya seorang penjamah makanan harus selalu menjaga kebrsihan tangan dengan cara mencuci tangan baik sebelum dan sesudah menjamah makanan. Kondisi yang tidak sesuai lainnya yang kaitannya dengan hygiene dan sanitasi pengolahan makanan adalah penggunaan serbet atau kain lap yang tidak memadai.

\section{Permasalahan Mitra}

Dari uraian analisis situasi di atas maka dapat diketahui beberapa permasalah mitra dalam kaitannya upaya peningkatan hygiene dan sanitasi pada pengolahan produk makanan mereka yaitu:

Tabel 1. Permasalahan yang dihadapi oleh para mitra pedagang rujak buah (lotis)

\section{Pedagang Rujak buah (Lotis) "Pak Uyan" \\ Pedagang Rujak buah (Lotis) "Pak Sihman"}

1. Keterbatasan modal yang dimiliki

2. Minimnya pengetahuan tentang penerapan 2 prinsip sanitasi pada pengolahan makanan

3. Gerobak yang digunakan dalam menjalan 3 . usaha rujak buah (lotis) belum memenuhi persyarata hygiene dan sanitas.

4. Hygiene personal yang kurang diperhatikan oleh para mitraMinimnya sarana untuk untuk menjaga kebersihan tubuh terutama kebersihan tangan mitra sebagai penjual rujak buah.

5. Belum digunakannya standar peralatan 5 . pelindung diri yang wajib dikenakan oleh para penjamah makanan (food handler).

6. Minimnya pengetahuan mitra tentang hygiene dan sanitasi pada pengolahan makanan.
1. Keterbatasan modal yang dimiliki

2. Minimnya pengetahuan tentang penerapan prinsip sanitasi pada pengolahan makanan

3. Gerobak yang digunakan dalam menjalan usaha rujak buah (lotis) belum memenuhi persyaratan hygiene dan sanitas.

4. Hygiene personal yang kurang diperhatikan oleh para mitraMinimnya sarana untuk untuk menjaga kebersihan tubuh terutama kebersihan tangan mitra sebagai penjual rujak buah.

Belum digunakannya standar peralatan pelindung diri yang wajib dikenakan oleh para penjamah makanan (food handler).

6. Minimnya pengetahuan mitra tentang hygiene dan sanitasi pada pengolahan makanan. 


\section{METODE PELAKSANAAN}

\section{Prosedur pelaksanaan}

Beberapa langkah-langkah yang dilakukan sebagai langkah solusi dalam permasalahan mitra yaitu sebagai berikut:

\section{Gerobak hygiene}

Langkah perancangan dan pembuatan gerobak hygiene ini ditujukan untuk mengatasi permasalahan mitra berupa belum digunakannya gerobak hygiene. Gerobak yang selama ini digunakan terbuat dari bahan kayu dan dilapisi cat kayu. Kondisi ini dinilai tidak ideal dan tidak sesuai dengan penerapan prinsip sanitasi maupun keamanan pangan. Program yang akan dilakukan yaitu dengan merancang gerobak hygiene yang sesuai dengan menggunakan bahan atau material logam seperti alumunium dan Stainless Steel yang tidak berbahaya bagi makanan. Selain itu pembuatan gerobak dengan bahan tersebut dapat tahan hingga bertahun-tahun sehingga diharapkan dapat menghemat biaya investasi. Perancangan gerobak dilakukan dengan tim teknis yang ada di lingkungan kampus UMS. Perancangan gerobak meliputi juga tata letak bahan makanan, peralatan serta perlengakapan yang akan dipakai saat gerobak beroperasi. Setelah proses perancangan selesai maka dilakukan pembuatan gerobak hygiene yang siap digunakan oleh para mitra.

\section{Peningkatan pengetahuan tentang hygiene dan sanitasi.}

Selama ini para mitra tidak mempunyai banyak pengetahuan tentang pentingnya hygiene dan sanitasi pada makanan. Hal ini terlihat dari perilaku para mitra yang mengabaikan kebersihan tangan dan kebersihan tubuh lainnya. Tidak adanya sarana cuci tangan (hand sanitizer) untuk menjaga kebersihan tangan baik pada saat akan mengolah maupun pada saat selesai mengolah makanan. Langkah yang dilakukan untuk solusi ini yaitu dengan memberikan booklet berisi tentang penerapan sistem sanitasi dan hygiene pada proses pengolahan makanan. Bookletyang diberikan berisi materi tentang sanitasi dan hygiene yang dikemas melalui gambar yang menarik, sehingga mitra akan mudah memahami tentang materi yang berkaitan dengan bagaimana cara meningkatkan kualitas makanan dari aspek kebersihan dan kesehatan.

\section{Peningkatan kesadaran untuk menjaga kebersihan diri.}

Langkah yang akan dilakukan untuk solusi ini yaitu dengan memberikan beberapa perlengakapan dan alat pelindung diri untuk menjaga terjadinya kontaminasi silang dari manusia ke makanan; dari alat ke makanan; maupun dari makanan mentah ke makanan yang siap dikonsumsi. Perlengkapan yang akan disediakan yaitu pakaian chef, topi, dan masker yang bertujuan untuk meningkatkan sanitasi dari produk yang dijual. Perlengkapan ini diberikan ketika para mitra sudah mendapatkan pengetahuan tentang pentingnya penerapan sanitasi dan hygiene pada pengolahan makanan.

\section{HASIL PELAKSANAAN KEGIATAN}

Beberapa rencana atau target luaran dari program Iptek bagi Masyarakat yang telah dicapai untuk mengatasi permasalahan mitra yaitu:

\section{Rancangan desain gerobak hygiene.}

Rancangan desain gerobak hygiene yang sudah dibuat diperuntukan untuk mengganti gerobak mitra yang dinilai tidak sesuai dengan prinsip penerapan hygiene dan sanitasi makanan. Adapun rancangan desain gerobak yang telah dibuat diantaranya mempertimbangkan hal-hal sebagai berikut:

\section{Pemilihan material yang dianggap aman serta berkategori bahan food grade.}

Material atau bahan logam yang dipilih dalam pembuatan gerobak hygiene untuk mitra yaitu berupa bahan logam alumunium dan stainless steel. Kedua bahan ini relatif tidak bersifat korosif. Kemudian kedua jenis logam ini juga tidak bereaksi ketika bersinggungan atau bersentuhan dengan makanan terutama sehingga akan lebih aman. Buah-buahan yang telah dikupas akan mudah 
mengalami kerusakan karena disebabkan karena adanya proses oksidasi dengan udara. Kemudian ketika buah tersebut bersentuhan dengan peralatan yang tidak hygiene maka akan mudah terkontaminasi. Selain itu juga material ini mudah sekali dibersihkan sehingga mudah dalam perawatan gerobak. Menurut Dewangan et al. (2015) material
Stainless Steel (SS) mempunyai karakteristik baja yang tahan karat dan mempunyai konstruksi yang sesuai untuk digunakan dalam peralatan makanan. Lebih lanjut Dewangan et al. (2015) menjelaskan bahwa material ini juga paling banyak digunakan dalam kontak langsung dengan makanan yang ditemukan pada industri makanan.
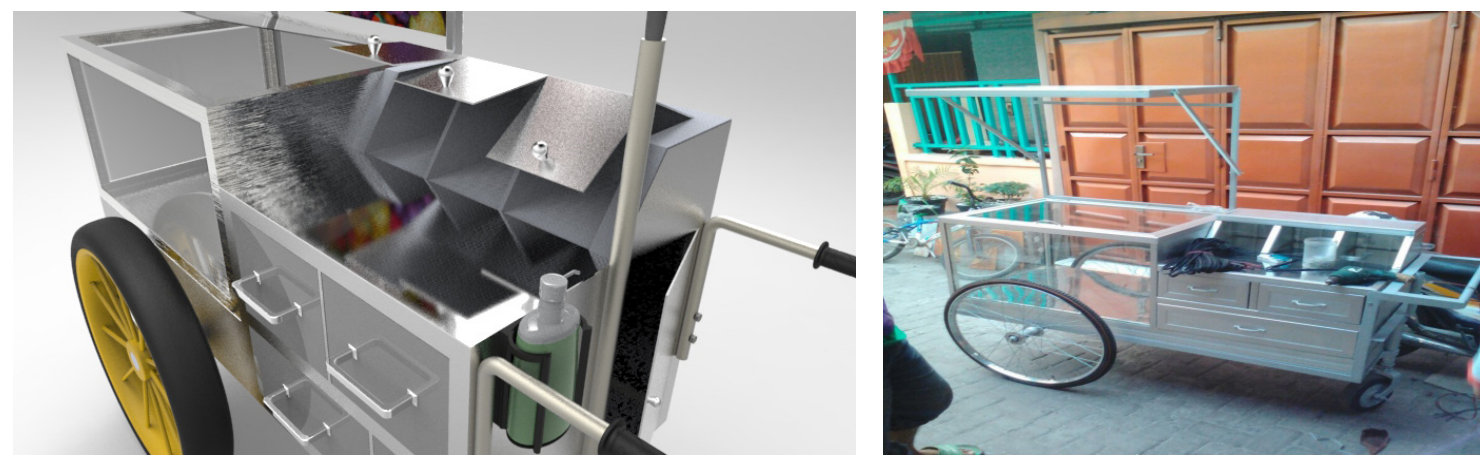

Gambar 1. Desain Gerobak dengan Material Alumunium Dan Stainless Steel

2. Tidak menggunakan bahan cat terutama pada bagian yang bersentuhan dengan makanan.

Penggunaan cat kimia pada bahan atau material yang bersentuhan dengan makanan dapat menyebabkan bahaya kimia maupun fisik pada makanan. Menurut Kenner (2001) bahaya fisik diakibatkan oleh penyertaan bahan-bahan asing yang tidak disengaja dalam produk akhir. Lebih lanjut Kenner
(2001) menjelaskan bahwa biasanya, bahan asing adalah sumber utama keluhan konsumen. Oleh karena itu rancangan desain gerobak hygiene yang akan diberikan kepada mitra didisain tanpa menggunakan cat kayu ataupun cat besi. Penggunaan cat pada material logam maupun kayu bisa berpotensi terkelupas, sehingga materi cat yang terkelupas bisa terikut pada makanan yang akan dikonsumsi.
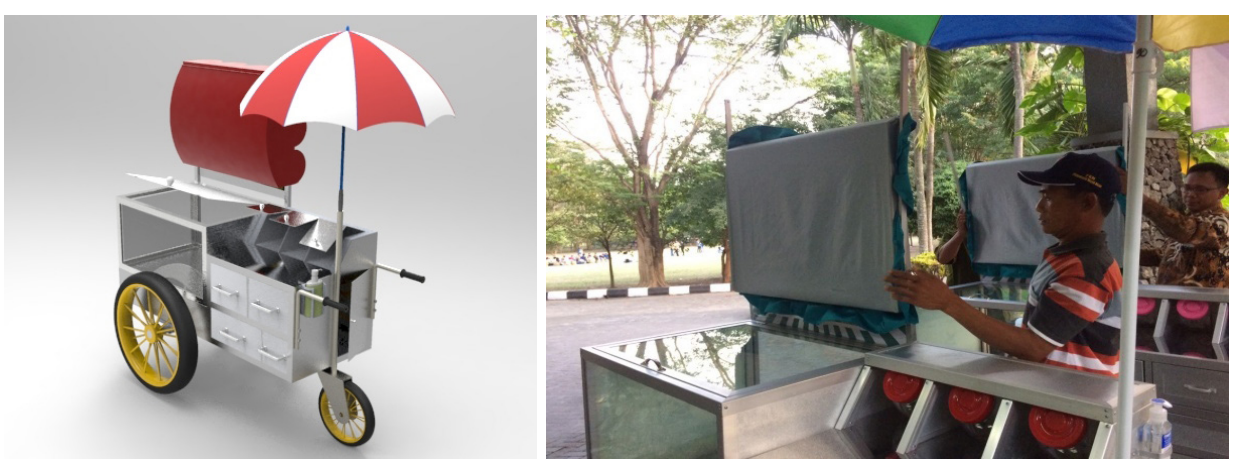

Gambar 2. Desain Gerobak tidak Menggunakan Cat pada Permukaan

\section{Desain gerobak hygiene dilengkapi dengan hand sanitizer}

Kebersihan diri (hygiene personal) penjaja makanan merupakan hal yang mutak harus dimiliki untuk memastikan bahwa produk makanan dan minuman yang akan dijual benar-benar bersih dan aman sehingga konsumenpun tidak dirugikan. Menurut Jeinie et al., (2016) pada umumnya minimnya pengetahuan tentang pentingnya menjaga kebersihan diri dan seringnya praktek pengolahan makanan yang tidak aman oleh food handler akan menyebabkan terjadinya penyakit yang disebabkan karena keracunan 
makanan foodborne illness. Kebersihan diri penjaja makanan dilakukan dengan cara menjaga kebersihan seluruh anggota badan serta berperilaku bersih. Kebersihan anggota tubuh yang harus selalu dijaga yaitu terutama tangan, karena anggota tubuh yang paling banyak melakukan kontak langsung dengan makanan yaitu telapak tangan. Oleh karena itu untuk menghindari kontaminasi penjaja makanan harus selalu membersihkan tangan setiap kali akan menjamah makanan. Desain gerobak yang dibuat dilengkapi dengan hand sanitizer, sehingga diharapkan mitra pedagang rujak buah (lotis) dapat menjaga kebersihan tangannya dengan menggunakan hand sanitizer yang sudah disediakan.
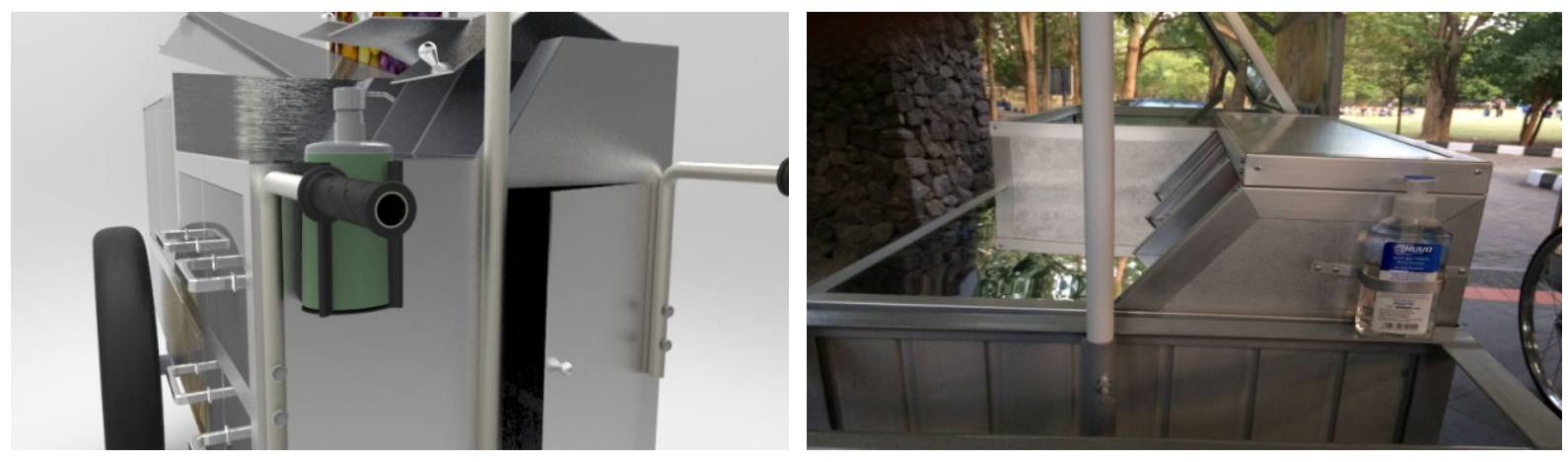

Gambar 3. Desain Gerobak dilengkapi dengan hand sanitizer

\section{Kapasitas untuk tempat buah segar diperbesar}

Hasil komunikasi dan wawancara dengan mitra diketahui bahwa mitra menghendaki peningkatan volume penjualan. Oleh karena itu mitra menginginkan dimensi khususnya pada bagian ruang kota buah diperbesar lagi. Desain gerobak dibuat sesuai dengan permintaan mitra, dengan memperbesar ukuran kotak buah menjadi $45 \mathrm{~cm}$ x $60 \mathrm{~cm}$ x $85 \mathrm{~cm}$, dimana dimensi/ukuran kotak buah pada gerobak sebelumnya hanya $35 \mathrm{~cm} \mathrm{x}$ $60 \mathrm{~cm} \times 70 \mathrm{~cm}$. Hal ini diharapkan dengan adanya penambahan dimensi ukuran tersebut dapat meningkatkan volume penjualan setiap harinya.
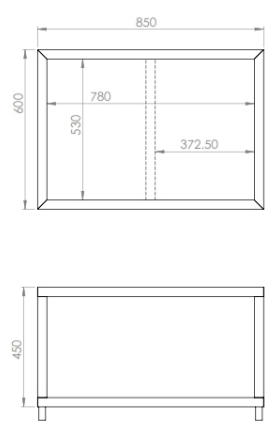
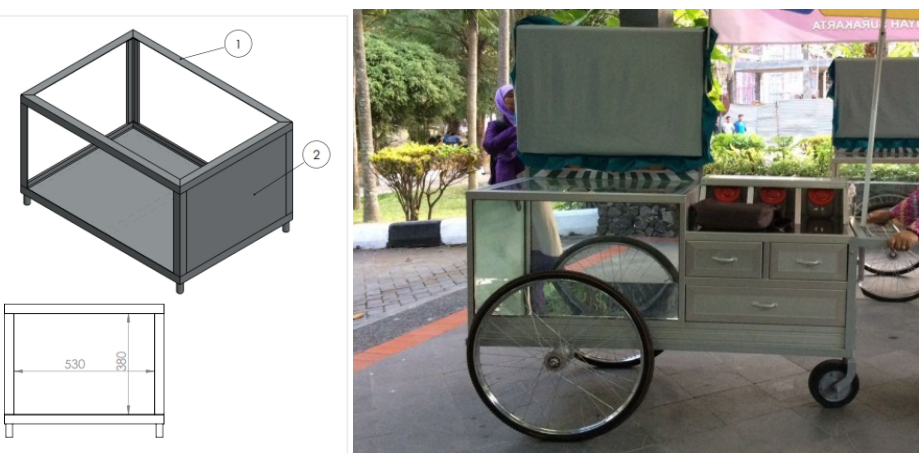

Gambar 4. Volume Kotak Buah Pada Gerobak Diperbesar

5. Desain laci dibagi menjadi beberapa ruang dengan fungsi yang berbeda

Desain gerobak yang dibuat memiliki tiga laci yang digunakan untuk tempat berbagai benda maupun peralatan lainnya yang berbeda. Laci yang dibuat akan digunakan sebagai tempat menyimpan uang, peralatan seperti piring, pisau, lap maupun buah dalam ukuran kecil sebagai cadangan ketika dibawa oleh mitra. Pembagian space atau ruang ini penting untuk menghindari kontaminasi silang antara peralatan dengan bahan makanan. Terutama uang hasil penjualan tidak boleh ditempatkan pada satu laci dengan peralatan makanan lainnya. Jika hal ini dilakukan maka uang sebagai sumber 
kontaminasi akan berpeluang mencemari peralatan yang akan digunakan. Menurut Rauf (2013) sumber kontaminasi pada makanan dapat berasal dari manusia, tanah, debu, serangga, udara, hewan, maupun alat yang digunakan untuk mengolah makanan.
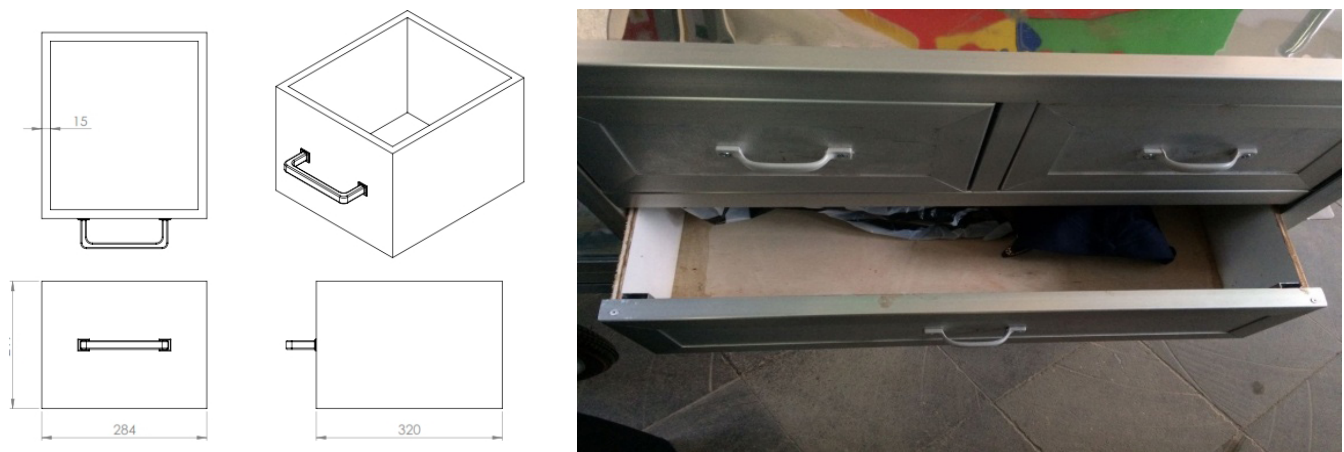

Gambar 5. Dimensi Ukuran Laci Gerobak Hygiene

\section{Gerobak hygiene dilengkapi dengan roda bantu dorong}

Gerobak untuk mitra yang juga dirancang dengan mempertimbangkan kemudahan dan kenyamanan bagi si pemakai (user). Beban penuh saat gerobak berisi buah yang siap dijual bisa mencapai lebih dari $100 \mathrm{~kg}$. Oleh karena itu perlu dirancang gerobak yang secara ergonomi memudahkan dan aman bagi si pengguna. Gerobak

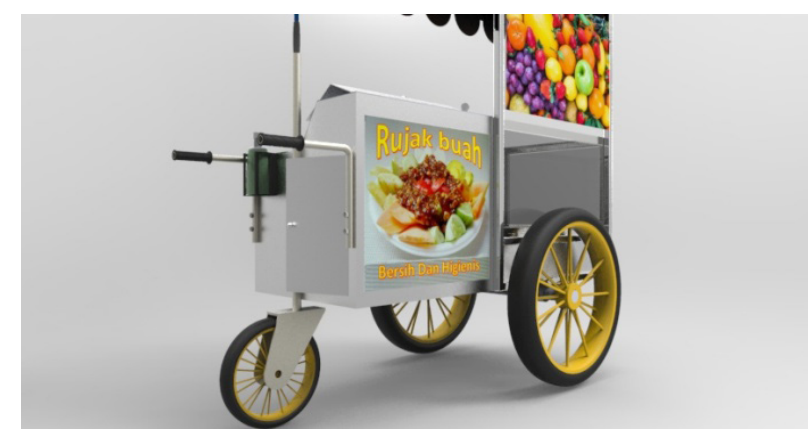

Gambar 6. Roda Bantu Dorong yang Ada Dibelakang Gerobak Hygiene sebelumnya tidak menggunakan roda bantu dorong pada bagian belakang, sehingga si pengguna harus mengelauarkan gaya untuk mengangkat sekaligus mendorong gerobak. Hal ini tentunya akan berdampak buruk bagi kesehatan dalam jangka waktu yan panjang. Gerobak yang didesain untuk mitra dilengkapi dengan roda bantu untuk meminimalkan gaya angkat maupun gaya dorong yang dikeluarkan pada saat bekerja.

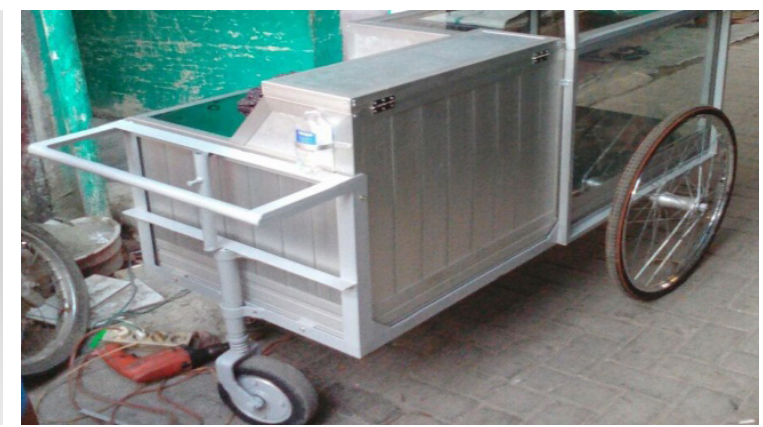

mungkin produk makanan tidak sampai terkena debu. Gerobak yang dibaut untuk mitra dilengkapi dengan atap yang berfungsi untuk meminimalkan peluang masuknya debu ke dalam buah-buahan yang siap untuk dibeli oleh para konsumen. 

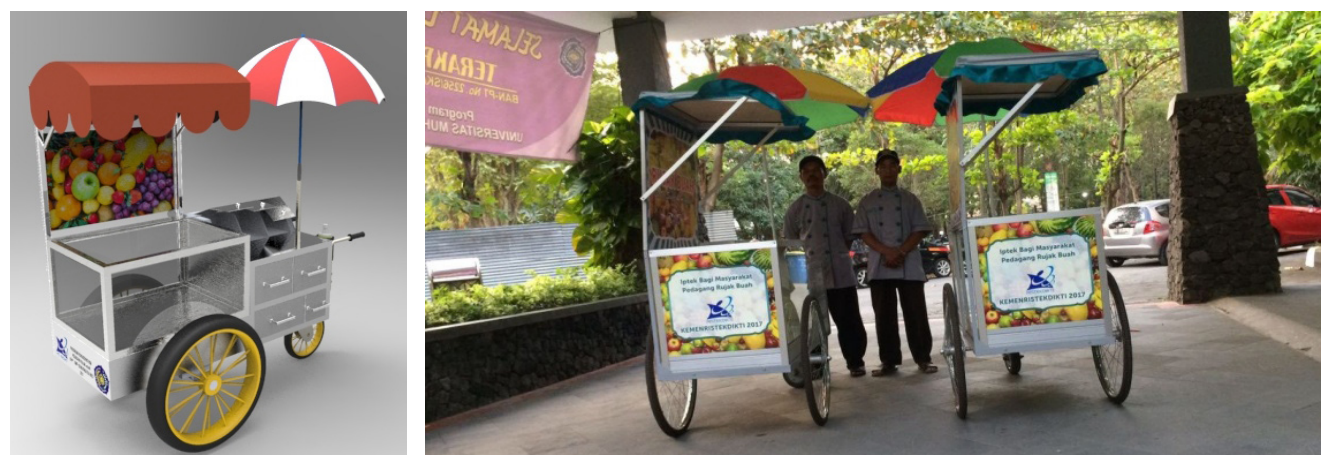

Gambar 7. Gerobak Hygiene Dilengkapi dengan Atap

8. Gerobak diberikan identitas si pemilik (mitra)

Identitas merupakan hal sangat penting terutama bagi para pedagang untuk memudahkan para konsumen atau pelanggan mengenali tempat maupun barang dagangan yang akan dibelinya. Dengan identitas ini juga bisa menjadi brand sehingga pedagang tidak salah dalam memilih barang. Identitas yang ditulis merupakan nama si penjual sekaligus jenis barang yang ditawarkan kepada konsumen. Selain itu dengan adanya MMT ini dapat mempercantik tampilan gerobak sehingga diharapkan lebih bisa menarik minat para konsumen.
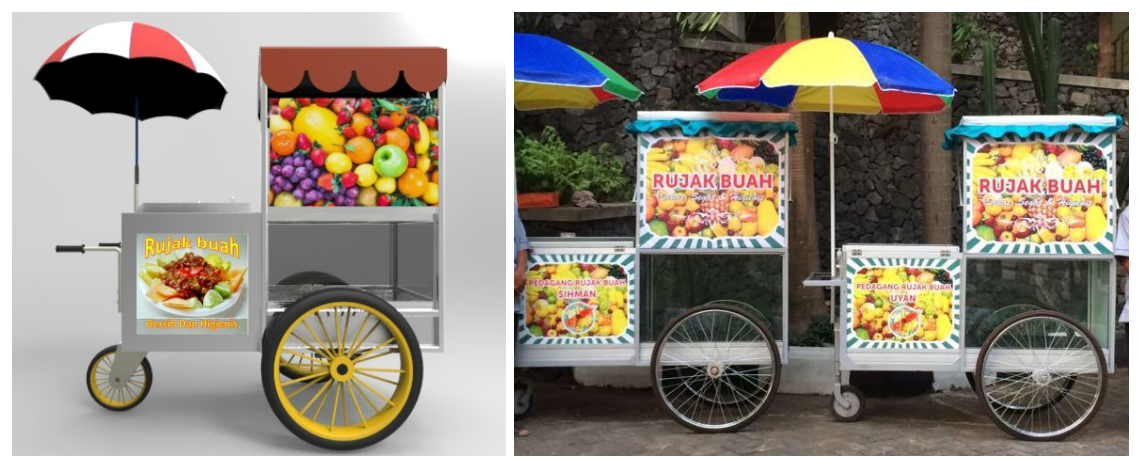

Gambar 8. Gerobak Hygiene dilengkapai dengan Identitas pemilik usaha

\section{Peningkatan Pengetahuan Tentang Hygiene dan Sanitasi}

Untuk meningkatkan pengetahuan tentang hygiene dan sanitasi dalam mengolah makanan oleh mitra maka diperlukan sebuah media pengetahuan berupa buku pedoman yang dibuat dalam format booklet. Buku pedoman didesain dengan mempertimbangkan kemudahan si pembaca atau si pengguna dalam memahami pengetahuan yang akan diberikan. Oleh karena itu pada buku panduan lebih diutamakan pada gambar yang lugas sehingga dari gambar yang ada si pengguna langsung bisa memahami dan mengerti maksud yang ingin disampaikan.

Konten yang ada pada buku panduan berisi tentang bagaiamana cara merawat dan mempertahnkan kerbersihan bahan makanan, peralatan yang digunakan selama mengolah makanan serta bagaimana cara menjaga kebersihan diri sehingga produk tidak terjadi kontaminasi silang. Menurut hasil penelitian Ismail et al. (2016) menyatakan bahwa ada korelasi positif antara pengetahuan tentang keamanan pangan dengan kebersihan diri (hygiene personal) dan food hygiene practices para pedagang kaki lima yang menjual makanan. 


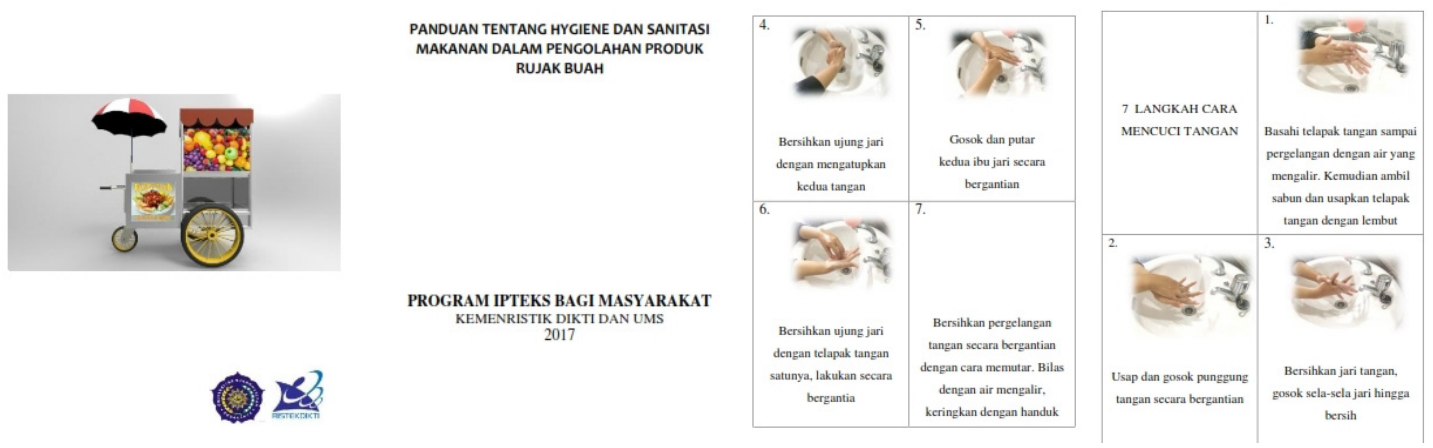

Gambar 9. Konten yang Ada Pada Panduan Hygiene dan Sanitasi

\section{Peningkatan Kesadaran untuk Menjaga} Kebersihan Diri

Setelah diberikan panduan tentang hygienedansanitasidalammengolahmakanan oleh mitra maka kemudian mitra diberikan perlengkapan untuk menjaga kebersihan diri.
Perlenngkapan yang diberikan oleh mitra yaitu berupa Baju Hygiene dan Topi. Baju dan topi yang diberikan berfungsi untuk mencegah terjadinya kontaminasi dari badan ke produk makanan. Selain itu juga bisa dijadikan sebuah identitias bagi mitra.
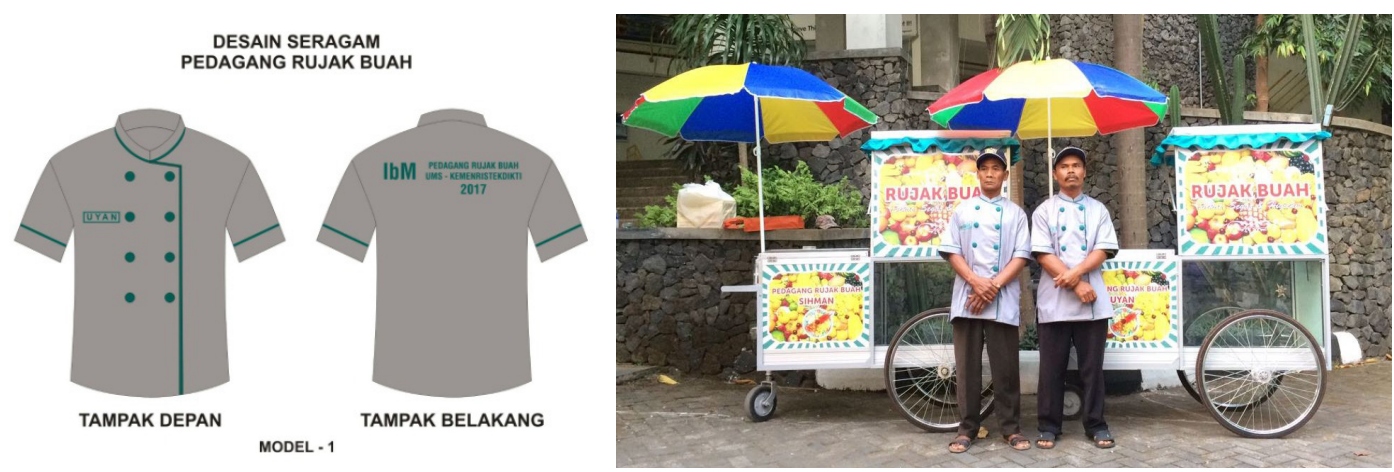

Gambar 10. Desain Baju untuk Menjaga Kebersihan Diri

\section{KESIMPULAN DAN SARAN}

\section{Kesimpulan}

Dari hasil pelaksanaan program IbM pada pedagang rujak buah (lotis) yang telah dilakukan dapat disimpulkan:

1. Program iptek bagimasyarakatyang telah dilakukan dapat mengatasi persoalan yang dihadapi oleh mitra terutama dalam pengadaan sarana gerobak yang lebih hygiene dari sebelumnya.

2. Program ini juga membantu para mitra dalam meningkatkan pengetahuan tentang pentingnya menjaga dan menjalankan prinsip hygiene dan sanitasi pada pengolahan makanan.

3. Produk yang dihasilkan memiliki kualitas yang lebih baik dari aspek kebersihan dan keamanan pangan sehingga akan menambah kepercayaan konsumen.

\section{Saran}

Perlu dilakukan pemeriksaan atau audit oleh auditor keamanan pangan sehingga penggunan gerobak hygiene benar-benar dapat menghasilkan produk olahan buah atau rujak lotis yang aman.

\section{DAFTAR PUSTAKA}

Dewangan, A. K., Patel, A. D., Bhadania, A. G. Stainless Steel for Dairy and Food Industry: A Review. J Material Sci Eng 2015, 4:5 
p ISSN: 1410-9344, e ISSN: 2549-5631

Isamil, F. H., Chik, C. T., Muhammad, R., Yusoff, M. N. 2016. Food Safety Knowledge and Personal Hygiene Practices amongst Mobile Food Handlers in Shah Alam, Selangor. Procedia - Social and Behavioral Sciences 222 ( 2016 ) 290-298

Jeinie, M. H., Nor, N. M., Sharif, M. S. M., Saad, M. 2016. Food Hygiene and Safety among Culinary Intern: Questionnaire for FHS quality. Procedia - Social and Behavioral Sciences 222 ( 2016 ) $299-305$

Keener, L. 2001. Chemical and Physical Hazards: The "Other” Food Safety Risk. Reproduced From Food Testing \& Analysis: The Target Group.

Maria, M., Anshori, M. Y. 2013. Jurnal Pengaruh Kualitas Produk dan Kualitas Layanan Terhadap Kepuasan Konsumen King Cake. Jurnal Manajemen Teori dan Terapan: Tahun 6. No. 1, April 2013

Rauf, R. 2013. Sanitasi Pangan dan HACCP. Yogyakarta: Penerbit Cahaya Ilmu

Rickman, J. C., Barrett, D. M., Bruhn, C. M. 2007. Nutritional comparison of fresh, frozen and canned fruits and vegetables. Part 1. Vitamins C and B and phenolic compounds. Journal of the Science of Food and Agriculture: 87:930-944. 